\title{
TITLE:
}

\section{Adenomyomatosis of the Gallbladder}

\section{$\operatorname{AUTHOR}(S)$ :}

NAGASE, MASAO; NISHIJIMA, YOSHINOBU; KIDO, SUSUMU; SETOYAMA, MOTOICHI; FUJIMURA, MASAKI

\section{CITATION:}

NAGASE, MASAO ...[et al]. Adenomyomatosis of the Gallbladder. 日本外 科宝函 1974, 43(5): 384-389

\section{ISSUE DATE:}

1974-09-01

URL:

http://hdl.handle.net/2433/208027

RIGHT: 


\title{
Adenomyomatosis of the Gallbladder
}

\author{
by \\ Masao Nagase, Yoshinobu Nishijima, Susumu Kido, \\ Motorchi Setoyama and Masaki Fujimura \\ The Department of Surgery, Yamato-Takada City Hospital
}

Adenomyomatosis is one of the hyperplastic cholecystoses (Table 1$)^{1)}$ and is characterized by hyperplasia of the muscle layer and of the mucosa. The mucosal folds are increased in number and depth and project into or through the muscle layer (RoKITANSKY-AschofF sinuses).

The lesions exist in three main forms : generalized, segmental and fundal (Fig. 1$)^{4}$ ). Table $2^{1)}$ summarizes the synonyms of adenomyomatosis.

The cholecystographic demonstration of ROKITANSKY-AschOFF sinuses was first described by MARCH in 1948'), and since then many case reports have been presented by JUTRAS et $\mathrm{a}^{3)}$., Colquhoun ${ }^{11}$, Aguirre et al.5), Bevan ${ }^{6)}$ and SHAPIRO ${ }^{7}$. The typical roentgenographic findings of adenomyomatosis is small dimpled filling defect at the fundus of the gallbladder, often accompanied by a kinking deformity of the body, or by a more generalized irregularrity of the out-

Table 1. Cholęcystoses ${ }^{1}$ )
1. Adenomyomatosis
2. Cholesterosis
3. Neuromatosis
4. Lipomatosis
5. Fibromatosis
6. Hyalinocalcinosis (calcified gallbladder)

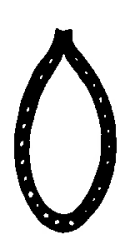

A. Generalised

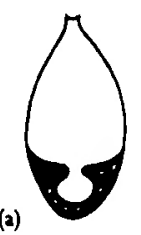

(a)

(b)

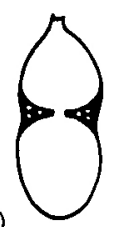

(b)

B. SEGMENTAL

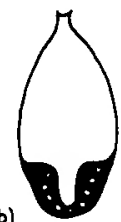

C. FUNDAL LESIONS

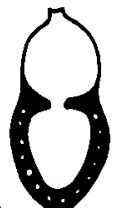

(c)
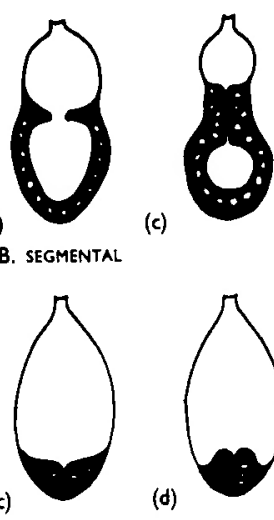

(d)

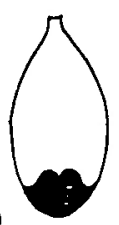

The commoner varieties of the three types of adenomyomatosis as seen in longitudinal section.

Fig. 14)

Table 2. Adenomyomatosis ${ }^{1)}$

\section{TYPES}

Diffused:

generalized segmental

Nodular:

usually localized at fundus
SYNONYMS

Rokitansky-Aschoff sinuses (Rokitansky, 1842, Aschoff, 1905)

Cholecystitis cystica (Bodnar, 1922)

Cholecystitis glandularis proliferans (King and MacCallum, 1931)

Intramural diverticulosis (March, 1948)

Epitheliomyoma (Caroli et al., 1951)

Gallbladder dysplasia (Albot et al. 1954)

Adenomyoma (Sutherland, 1898)

Adenoma (Aschoff, 1905)

Hamartoma (Abell, 1923)

Adenofibroma (Weidinger, 1928)

Cystadenoma (Kordenat, 1930)

Myo-epithelial anomaly (Jones and Walker, 1957) 
lines of the gallbladder caused by contrast material entering the R-A sinuses ${ }^{6}$.

The clinical significance and management of this lesion have been a subject of controversy. Because of the frequency with which some degree of adenomyomatosis may be found in surgical specimens, as high as 33.3 per cent in 2,490 cholecystectomies (JUTRAS ) ${ }^{3}$, it is certain that the most lesions produce no symtoms.

When gallstones coexist with the lesions as shown in two of our cases, the therapeutic problem is simplified. In the absence of gallstone, however, many surgeons are unwilling to remove the gallbladder which has normal functions radiologically.

According to COLQUHOUN" ${ }^{4}$, adenomyomatosis alone is probably no more an indication for cholecystectomy than are uncomplicated gallstones. And operation depend on the severity of symtoms and the likelihood of complications; it should be noted that adenomyomatosis is rarely, if ever, a cause of malignancy in spite of its proliferative features.

JUTRAS et al $^{11}$ have seen a sufficiently large number of seriously ill distressed persons recover immediate and lasting health after cholecystectomy.

BEVAN $\left.{ }^{6}\right)$ reported the course of acalculous adenomyomatosis in 6 patients, and suggested that, even in the absence of gallstones, cholecystectomy should be advised when this condition is demonstrated radiographically in symptomatic subjects. Moreover, unsuspected presence of a carcinoma in one of his patients provided reason for caution in assuming that this condition always follow a benign course.

The course of adenomyomatosis of the gallbladder in 4 patients is described as follows.

Case 1.

Y.H., a 37-year-old man, had had epigastric discomfort after meals for several years, and recently has experienced episodes of right upper quadrant colic after fatty meals. There was no history of jaundice or fever. Physical examinations showed no abnormalities. Liver function tersts were all within normal limits. A barium study. of the upper gastrointenstinal tract

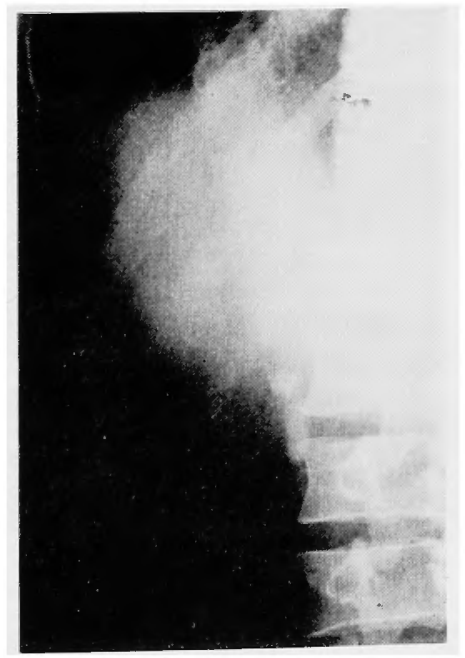

Fig. 2

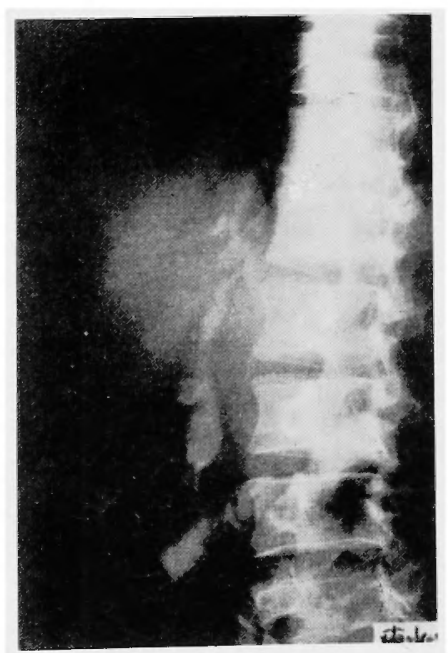

Fig. 3 


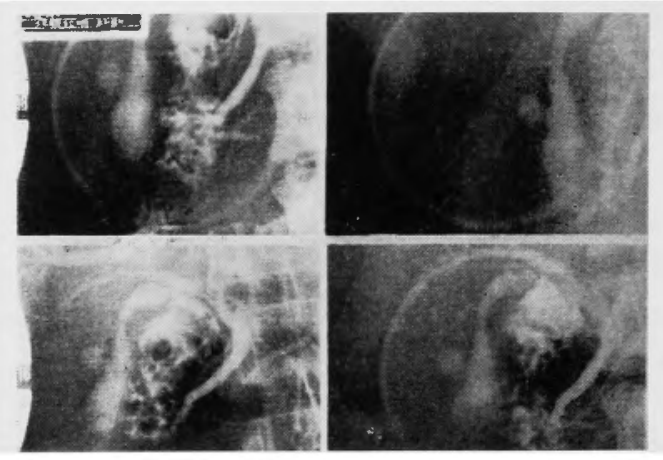

Fig. 4

revealed a small scar of duodenal ulcer.

His oral cholecystogram and drip infusion cholangiogram are shown in Figs. 2 and 3 , and the endoscopic cholangiogram is shown in Fig. 4.

Cholecystectomy was done on the diagnosis of diverticula of the galibladder wall and probably sands in the organ. The wall of the gallbladder thickened remarkably and had many diverticula containing sands (Fig. 5). The histologic findings were those of adenomyomatosis (Fig. 6).

Postoperative course was uneventful and the patient lost all his symptoms.
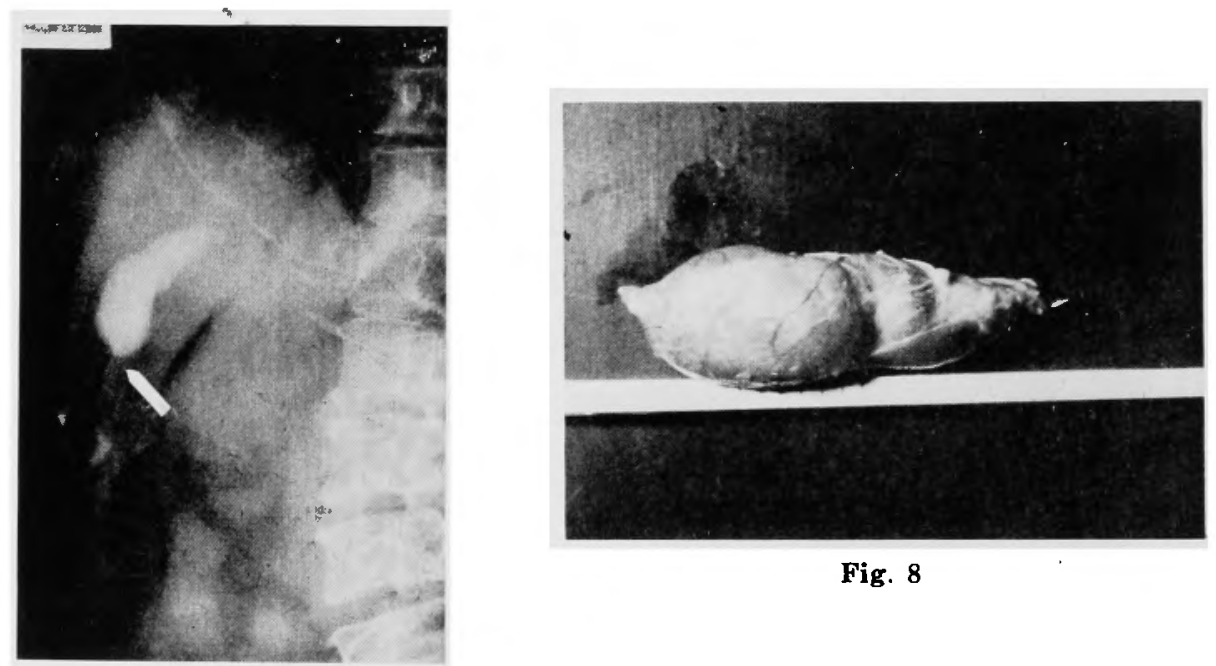

Fig. 8

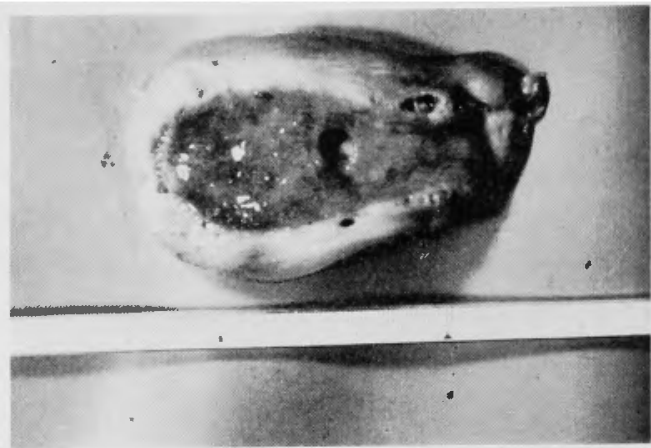

Fig. 5

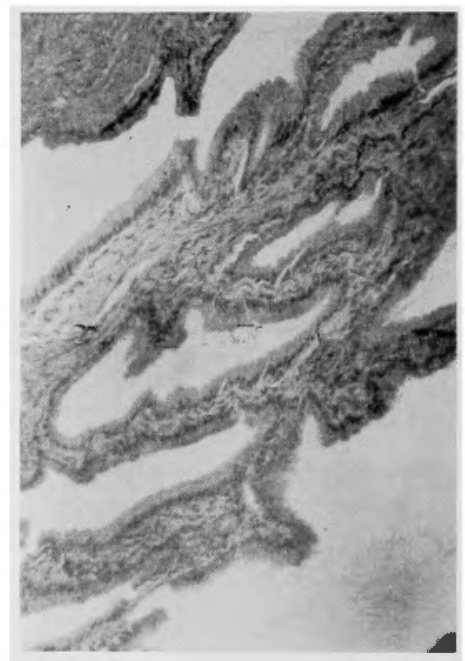

Fig. 6

Fig. 7 
Case 2 .

F.O., a woman aged 50 years, complained of slight upper abdominal pain for about six months.

Physical findings were normal except for hypertension and hyperlipemia.

Her oral cholecystogram showed a fixed filling defect at the fundus. (Fig. 7).

Cholecystectomy was carried out on suspicion of a cholesterol polyp of the gallbladder wall. The gallbladder was found to contain a small button of tissue at the fundus, but no calculi (Fig.8). The histologic findings were characteristic of adenomyomatosis.

Following cholecystectomy the patient remained asymptomatic.

Case 3 .

S.M., a 54-year-old woman, had experienced upper abdominal pain for four years.

A barium study of the upper gastrointestinal tract revealed a gastric ulcer, and a drip infusion cholangiography showed a deformity of the gallbladder (Fig.9).

Gastrectomy (B-I) was carried out, and a small button of tissue at the fundus was excised (Fig.10). Typical findings of adenomyomatosis were seen in histologic sections (Fig.11).

Postoperative course was uneventful and the patients has remained well.

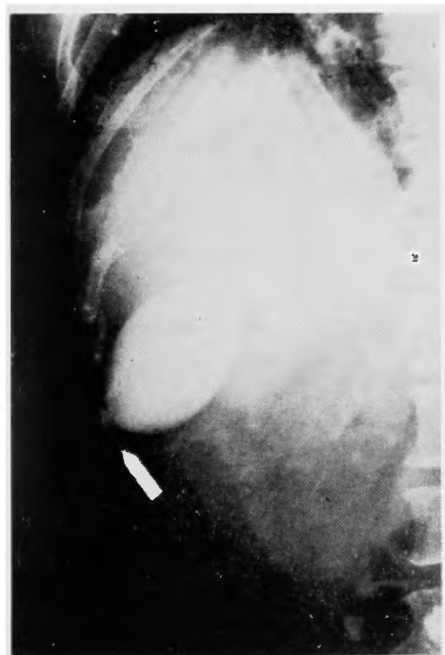

Fig. 9

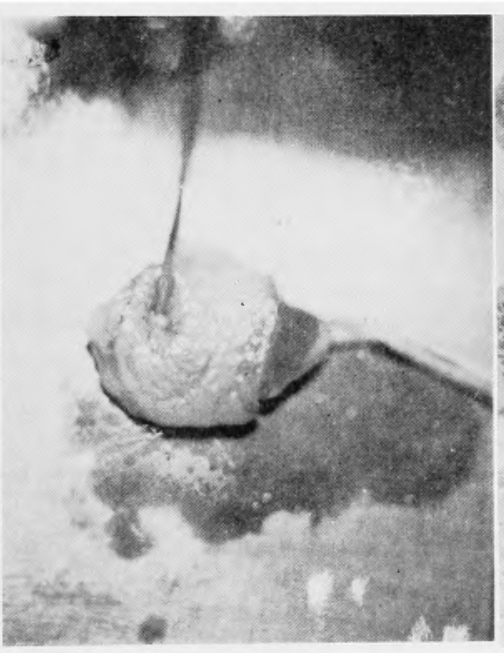

Fig. 10

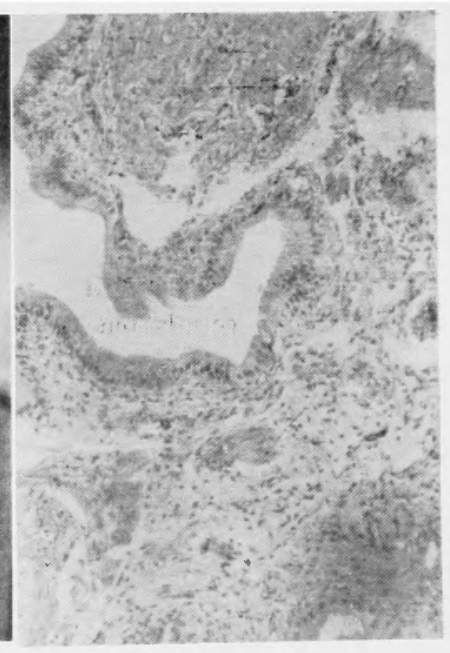

Fig. 11

Case 4.

N.H., a man of 62 years old, complained of right upper quadrant colic and recurrent episodes of jaundice for one month.

Liver function tests were as follows: Total bilirubin $1.87 \mathrm{mg} \mathrm{dl}$, GOT 89 , GPT 99 and alkaline phosphatase $41.3 \mathrm{~K} . \mathrm{A}$.U. Oral and intravenous cholangiograms were not diagnotic. Percuataneous transhepatic cholangiography revealed stones in the dilated common duct (Fig. 12).

At operation, faceted inflammatory stones were found in the dilated common duct and in the gallbladder, and the latter hypertrophied markedly and contained a small button of 


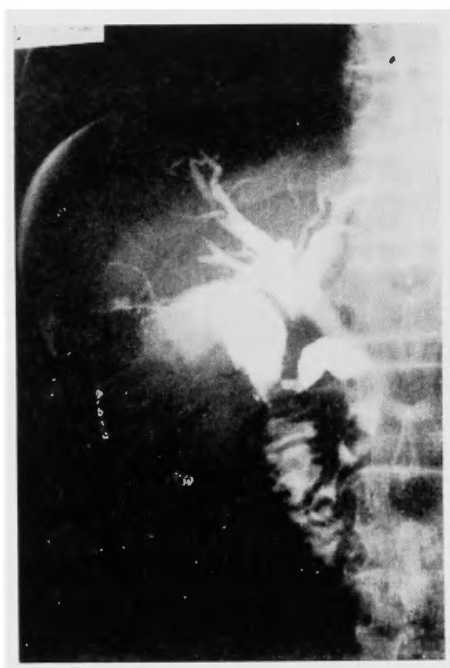

Fig. 12

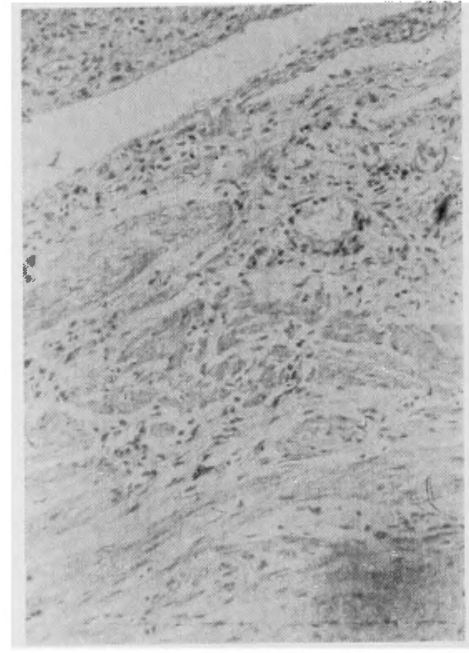

Fig. 13

tissue at the fundus. Cholecystectomy and external choledochostomy were carried out. Histologic findings of the fundus were those of adenomyomatosis (Fig. 12). Postoperative course was uneventful and the patient lost all his symptoms.

The authors wish to express their sincere gratitude to Prof. Dr. Yorinori Hikasa for his kind guidance.

\section{References}

1) Jutras, A. and Levesque, H.: Adenomyoma and adenomyomatosis of the gallbladder, Radiologic and pathologic correlations. Radiol. Clin. North Amer., $4:$ 483, 1966.

2) March, H.C. : Visualization of the Rokitansky-Aschoff sinuses of the gallbladder during cholecystography. Amer. J. Roentgenol., 59 : 197, 1948.

3) Jutras, A. et al. : Hyperplastic cholesystoses. Amer. J. Roentgenol., $83: 795,1960$.

4) Colquhoun, J. : Adenomyomatosis of the gallbladder (Intramural diverticulosis). Brit. J. Radiol., 54:101, 1961.

5) Aguirre, J. R. et al. Hyperplastic cholecystoses; A new contribution to the unitarian theory. Amer. J. Rcentgenol., $107: 1,1969$.

6) Bevan, G. : Acalculous adenomyomatosis of the gallbladder. Gut, $11: 1029,1970$.

7) Shapiro, R. : Fixed defects of the gallbladder wall and adenomyomatosis. Surg. Gynec. Obstet., $136: 745,1973$. 


\title{
和交抄録
}

\author{
胆霬アデノミオーマトージス \\ 大和高田市立病院外科
}

長瀬正夫，西嶋義信，木戸 晋 瀬戸山元一, 藤 村 昌 樹

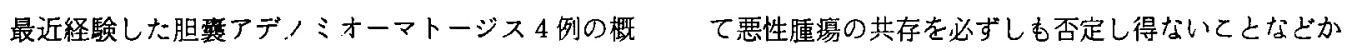
要を報告した.

ら，症状を有する患者でレントゲン学的に本症を発見

胆石を伴わない本症でも症状を発し得るとと, 且つ した時には，たとえ胆石がなくとも積極的䎲手術を行 胆裔切除術により治瘾させ得るとと，また文献からみ なうべきである。 